\title{
Investigation of Latvian Rivers in Lowland and Hilly Areas by Using the Hydrogeological Model of Latvia
}

\section{Latvijas zemieņu un augstieṇu upju īpašību pētī̌sana ar Latvijas hidroǵeoloǵiskā modeḷa palīdzību}

\author{
Kaspars Krauklis ${ }^{1}$, Aivars Spalviņš ${ }^{2}$, Irīna Eglīte ${ }^{3}$ \\ ${ }^{1-3}$ Rīgas Tehniskā universitàte, Latvija
}

\begin{abstract}
Kopsavilkums - Upju sateces baseinu (SB) principu pazemes ūdensobjektu noteikšanai rekomendē Eiropas Savienības galvenā ūdens direktīva. Šis princips tiek lietots arī Latvijā. Izmantojot Latvijas hidrog̀eoloğisko modeli, RTU zinātnieki 2015. gadā konstatējuši, ka SB princips Iecavas upei nav lietojams, jo upe saṇem pazemes ūdeni no apgabaliem, kuri atrodas tālu no tās SB areāla. Šis raksts informē par skaitlisko eksperimentu rezultātu zemieṇu un augstieṇu upju (Iecavas un Maltas) SB areāliem. Konstatēts, ka SB principu var izmantot tikai šo upju kvartāra slān̄i. Jo dziḷāk atrodas ūdeni saturošais slānis, jo mazākā mērā tam var izmantot SB principu. Zemieṇu un augstieṇu upēm būtiski atškīrās pazemes ūdens plūsmu sadalījums pamatiežos, kuros Iecavas un Maltas upēm vertikālās plūsmas vērstas augšup un lejup, bet horizontālās plūsmas ieplūst un izplūst no SB areāla. Latvijā dzeramo ūdeni iegūst galvenokārt no pamatiežu ūdensgūtvēm, tāpēc pazemes ūdensobjektu robežas būs jākoriǵē, jo SB kritērijs pamatiežiem nav izmantojams
\end{abstract}

Atslēgas vārdi - Hidrog̀eoloğiskais modelis, MODPATH, pazemes ūdens plūsmu bilance, upes sateces baseins.

\section{IEVADS}

Pazemes ūdens resursu pārvaldībā pazemes ūdensobjektu robežu noteikšanai izmanto upju sateces baseinu principu (SB), t. i., uzskata, ka atmosfēras nokrišņi SB areālā ir vienīgais pazemes ūdens plūsmu avots visā SB tilpumā, kurā ietilpst arī dziḷākie ūdens horizonti. Eiropas Savienības galvenā ūdens direktīva [1] iesaka upes SB izmantot kā kritēriju pazemes ūdensobjektu robežu noteikšanai. Rīgas Tehniskās universitātes (RTU) Vides modelēšanas centra (VMC) speciālisti pārbaudīja, vai Iecavas upi baro nokrišņi tās SB areālā. Rezultāts bija negaidīts. Izrādījās, ka ievērojama daḷa pazemes ūdens ceḷo uz upi no augstienēm, kuras atrodas l̦oti tālu no SB. Arī SB areālā pazemes ūdens dạ̣iņu trajektorijas ir l̦oti komplicētas. Tika konstatēts, ka ar SB areālu var noteikt ūdensobjekta robežas tikai kvartāra pazemes ūdens horizontā. Jāatzīmē, ka šo rezultātu varēja iegūt tikai Latvijas hidroǵeoloǵiskā modeḷa (LAMO) vidē. LAMO aptver valsts teritorijas pazemes ūdens aktīvo zonu, kura ir aproksimēta ar 27 ǵeologiskajiem slāņiem (LAMO apraksts pārskatā [4]). Lokālos modeḷos pētîjumā [2], [3] iegūtos rezultātus iegūt nav iespējams.
Šajā rakstā ziṇots par sarežğîtākiem pētījumiem, kuru nolūks bija noskaidrot, vai SB princips ir spēkā zemieņu un augstieņu upju (Iecavas un Maltas) SB areālos.

Upju SB kritērija derīguma pārbaudi veicām ar divām metodēm: pazemes plūsmu bilances analīze un ar MODPATH eksperimentu [5].

Eksperimenti tika īstenoti divos MODPATH darbības režīmos: pazemes ūdens daļina kustās straumes virzienā (forward) un pret straumi (reverse). Forward režīms parāda, uz kurieni aizplūst ūdens no SB areāla, reverse režīmā var atrast avotus, kuru ūdens nonāk SB areālā. Ūdens dalịnas tika ievietotas to modeḷa šūnu centros, kuras atrodas SB areālā. Kā SB areāla robeža visos slāņos tika izmantota robeža Q2 horizontā. Robežas novietojumu noteica LAMO vidē ar Surfer [6] rīku Watershead.

\section{PAZEMES ŪDENS PLŪSMU BILANCE}

Pazemes ūdens plūsmu bilance iegūstama ar sistēmas Groundwater Vistas (GV) [7] rīku Mass balance. Bilance parāda, kā atmosfēras nokrišņi baro upes ezerus, ekspluatācijas urbumus un kāds pazemes ūdens daudzums šķērso SB areāla robežu.

Iecavas pazemes ūdens plūsmu bilance grafiskā formā skatāma 1. attēlā. Šeit attēloti trīs bilances detalizācijas pakāpes: 1) pilnā bilance, kurā dotas visas ar GV aprēķinātās plūsmas: vertikālā plūsma starp ūdens horizontiem, plūsma caur SB areāla robežu, upju un ezeru ūdens plūsmas; 2) lokālās bilances ūdens horizontiem; 3) lokālās bilances SB kopumā un tā kvartāram un pamatiežiem.

Ja plūsma caur horizonta robežu nav vienāda ar nulli, tad SB kritērijs nav izpildīts [8]. No 1. attēla var secināt, ka Q2 horizonta plūsma caur SB robežu 4,0 tūkst. $\mathrm{m}^{3} / \mathrm{dnn}$ ir 2,6\% no infiltrācijas plūsmas $\left(152,4\right.$ tūkst. $\mathrm{m}^{3} /$ dnn $)$, t. i., ka Q slān̄̄ SB areāla robeža apmierinoši atbilst SB kritērijam. Nevienam no citiem pazemes ūdens horizontiem SB kritērijs nepiepildās. Slāṇos D3dg\# un D3pl ūdens izplūst no SB areāla galvenokārt Daugavas ietekmes dēḷ. Pārējos Iecavas pamatiežu slāņos D3gj2, D3gj1, D2brt, D2ar ūdens SB areālā ieplūst. 

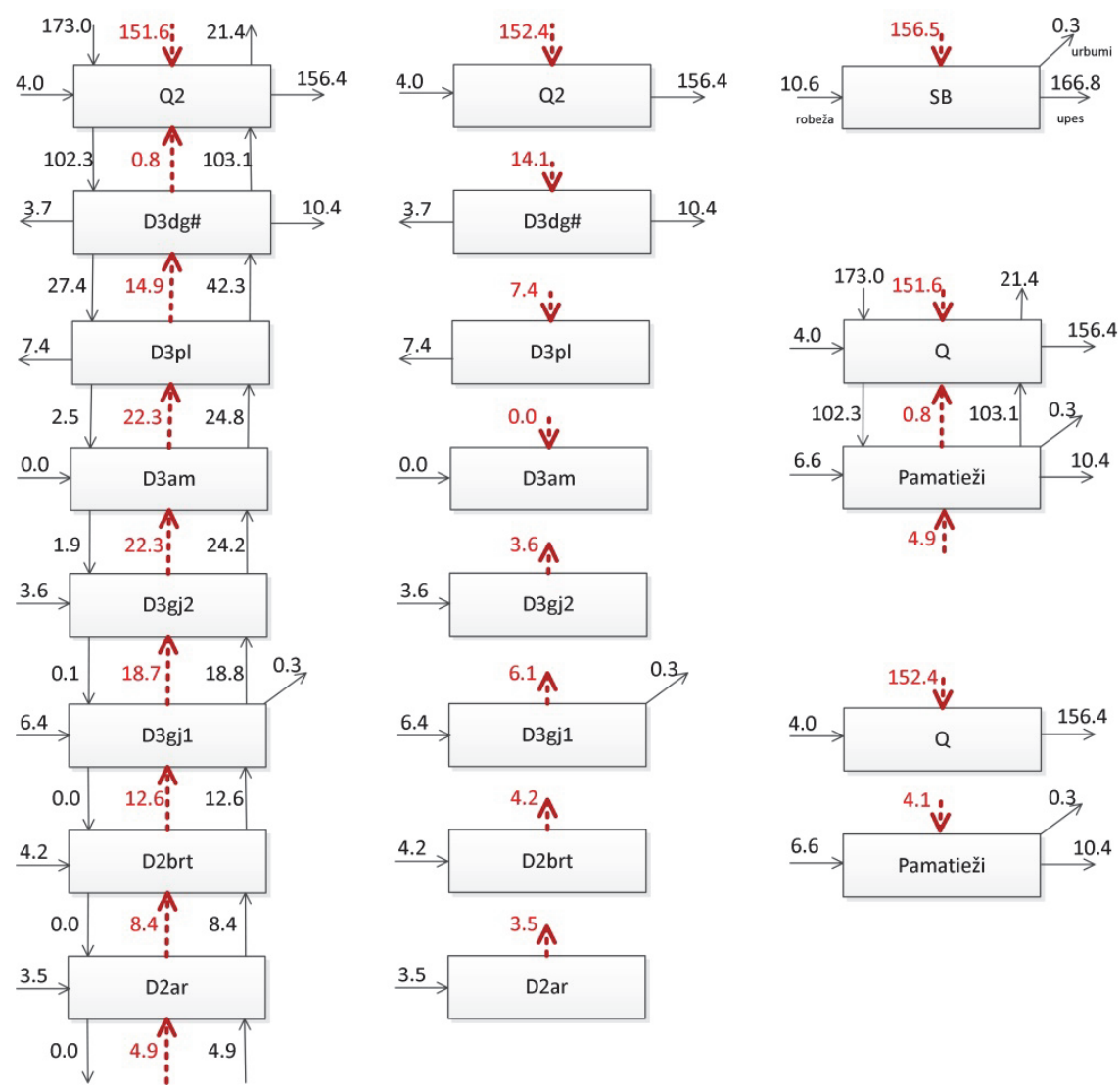

1. att. Ūdens bilance (tūkst. $\mathrm{m}^{3}$ / dnn) Iecavas SB.
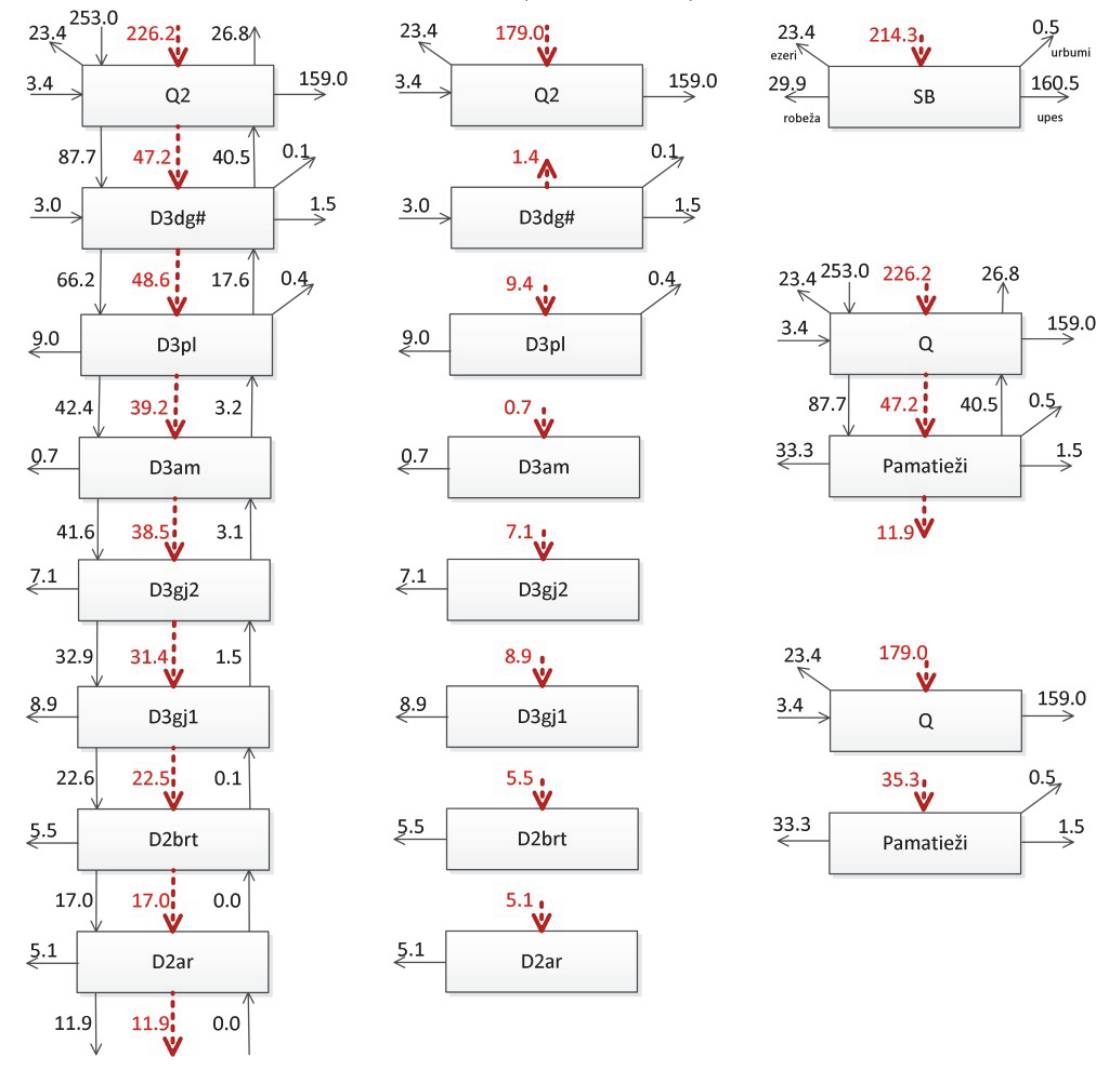

2. att. Ūdens plūsmu bilance (tūkst. $\mathrm{m}^{3} / \mathrm{dnn}$ ) Maltas SB. 
Visā SB areālā ir uz zemes virspusi vērstas rezultējošās vertikālās plūsmas starp ūdens slāniiem.

Maltas pazemes ūdens plūsmu bilance ir skatāma 2. attēlā. Maltas Q slānī plūsma caur SB robežu 3,4 tūkst. $\mathrm{m}^{3} / \mathrm{dnn}$ ir 1,9 \% no infiltrācijas plūsmas 179,0 tūkst. $\mathrm{m}^{3} / \mathrm{dnn}$, t. i., SB kritērijs šim slānim izpildās apmierinoši. Atšḳirībā no Iecavas Maltai ūdens izplūst no pamatiežu slāṇa un visur ir uz leju vērsta starpslāṇu plūsma. Nevienam Maltas SB pamatiežu horizontam SB kritērijs nav spēkā.

\section{AR MODPATH IEGŪTO REZULTĀTU STATISTIKA}

Abu pētāmo upju SB areālu šūnu centros ievieto pa vienai dalinai: Iecavas un Maltas SB, attiecīgi 17934 un 12556 dalinas. Eksperimentu veic forward un reverse režīmā slānim relh, Q2, D3dg\#, D3pl, D3am.

Forward režīmā noskaidro, cik dalinu sasniedz relh slāni (nokrišņu avotu) ārpus SB un cik paliek SB; cik daḷiņu nonāk upēs ārpus SB un cik paliek SB; cik dalinu sasniedz D2prn slāni ārpus SB un cik paliek SB.

Iecavai forward režīmā (3. att.) neviena daḷiṇa nenonāk D2prn slānī; galvenokārt daḷiņas nonāk upēs.

Maltai (4. att.) l̦oti daudzas dalinnas no dziḷākajiem slāņiem sasniedz D2prn slāni; gandrīz visas daḷiņas no relh, Q2 un D3dg\# nonāk upēs.

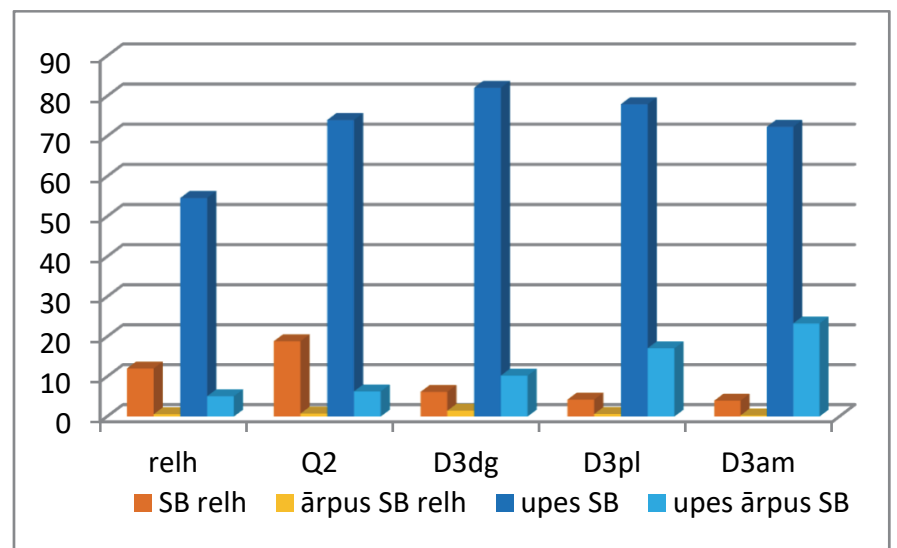

3. att. Iecavas SB daḷiņu kustības galapunktu sadalījums procentos forward režīmā.

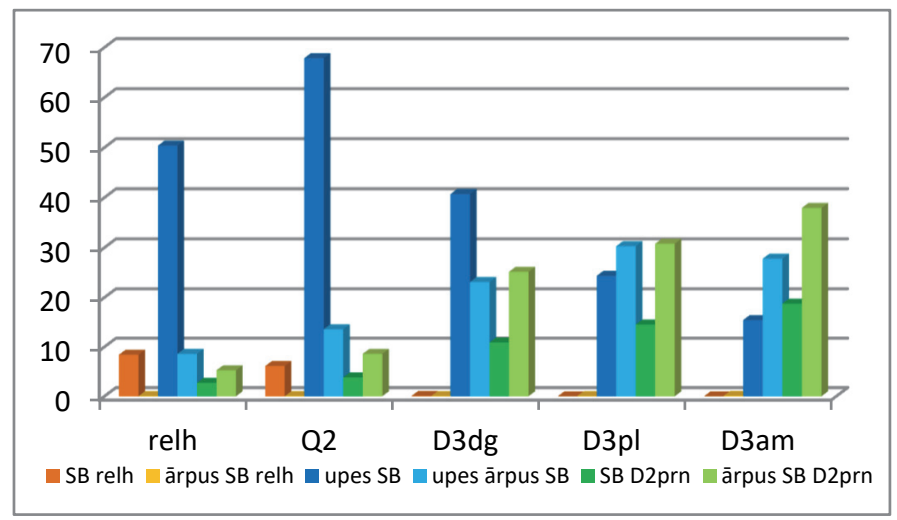

4. att. Maltas SB daḷinu kustības galapunktu sadalījums procentos forward režīmā.

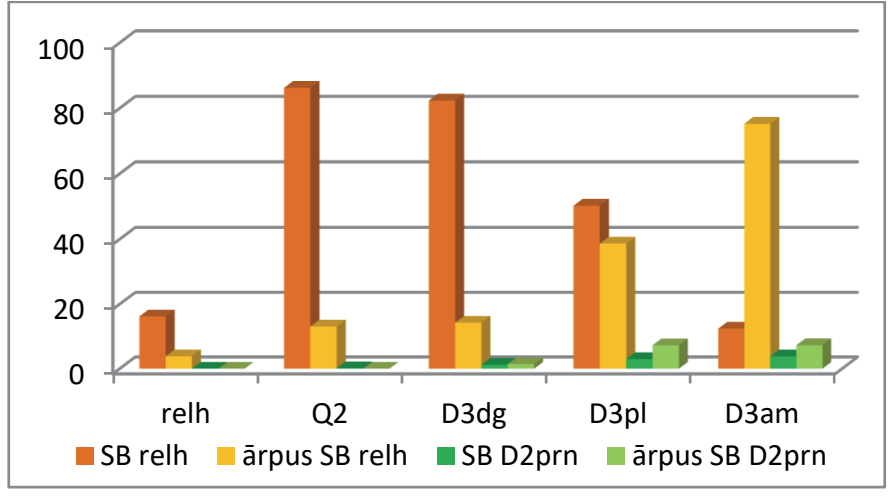

5. att. Iecavas SB dalịnu kustības galapunktu sadalījums procentos reverse režīmā.

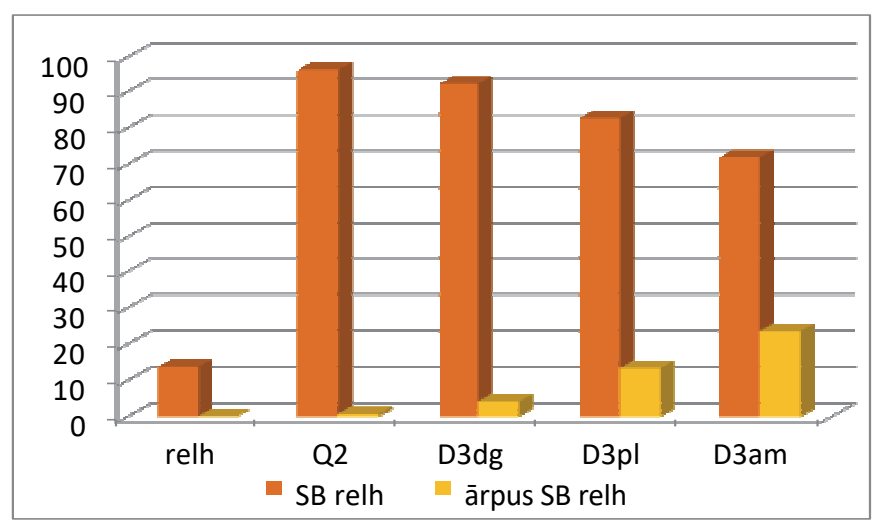

6. att. Maltas SB daḷiṇu kustības galapunktu sadalījums procentos reverse režīmā.

Reverse režīmā tiek aprēķināts, no kurienes SB areālā nonāk pazemes ūdens. Iecavas (5. att.) dalinnas nāk no relh (atmosfēras nokrišņi) un D2prn slāņa.

Maltai (6. att.) dal̦iņas nāk tikai no relh slāṇa. Reversā režīmā (īpaši relh slānī) daudzas dalinnas nekustas, t. i., pārstāv to dalinu kopu, kura darbojas forward režīmā.

Atšķirỉbas abu upju statistikas raksturā galvenokārt izsauc tas apstāklis, ka Iecavai un Maltai ir pretēji vertikālo ūdens plūsmu virzieni, attiecīgi augšup un lejup.

\section{DAḶIṆU KUSTĪBAS TRAJEKTORIJAS}

To ūdens dalinu kustības trajektoriju kopaina, kuras pamet SB areālu režīmā forward, ja ūdens dalininas startē no Q2 un D3am slāṇa, skatāma 7. attēlā un 8. attēlā.

Maltas gadījumam īpaši garas daļiņu trajektorijas ir Q2 un D3am slān,iem, t. i., no SB areāla izplūstošais ūdens sasniedz rajonus, kuri atrodas tālu no Maltas SB areāla.

Daḷinu kustības trajektorijas, kuras ieplūst SB areālā režīmā reverse no SB ārpuses, ir skatāmas 9. attēlā un 10. attēlā. Iecava sanem ūdeni arī no Vidzemes un Latgales augstienēm (apstiprina pētījumu [2]), bet Maltas SB pazemes ūdens plūst no lokālas augstienes, kuras atrodas tuvu Maltas SB. Abām upēm to dalinu skaits, kuras pamet (7. att.) vai ienāk (9. att.) Q2 slānī, ir neliels (salīdzinot ar kopējo dalinu skaitu), un tāpēc šajā slānī praktiski ir spēkā SB kritērijs, t. i., apstiprinās novērtējums, kuru dod pazemes plūsmu bilances analīze Q slānim. 


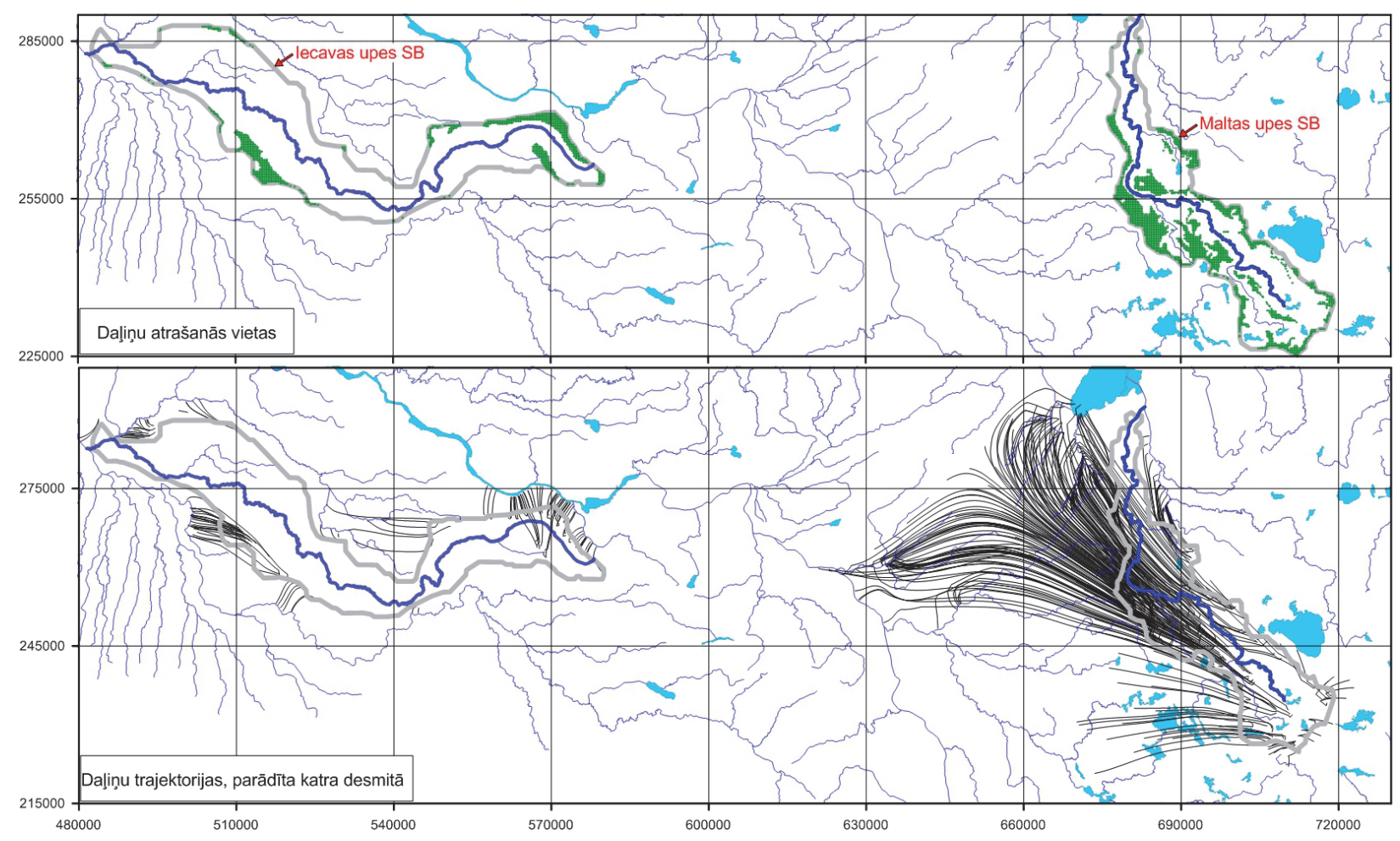

7. att. Dalịnu novietojums un trajektorijas, kas iziet ārpus SB, startējot Q2 slānī, forward režīms.

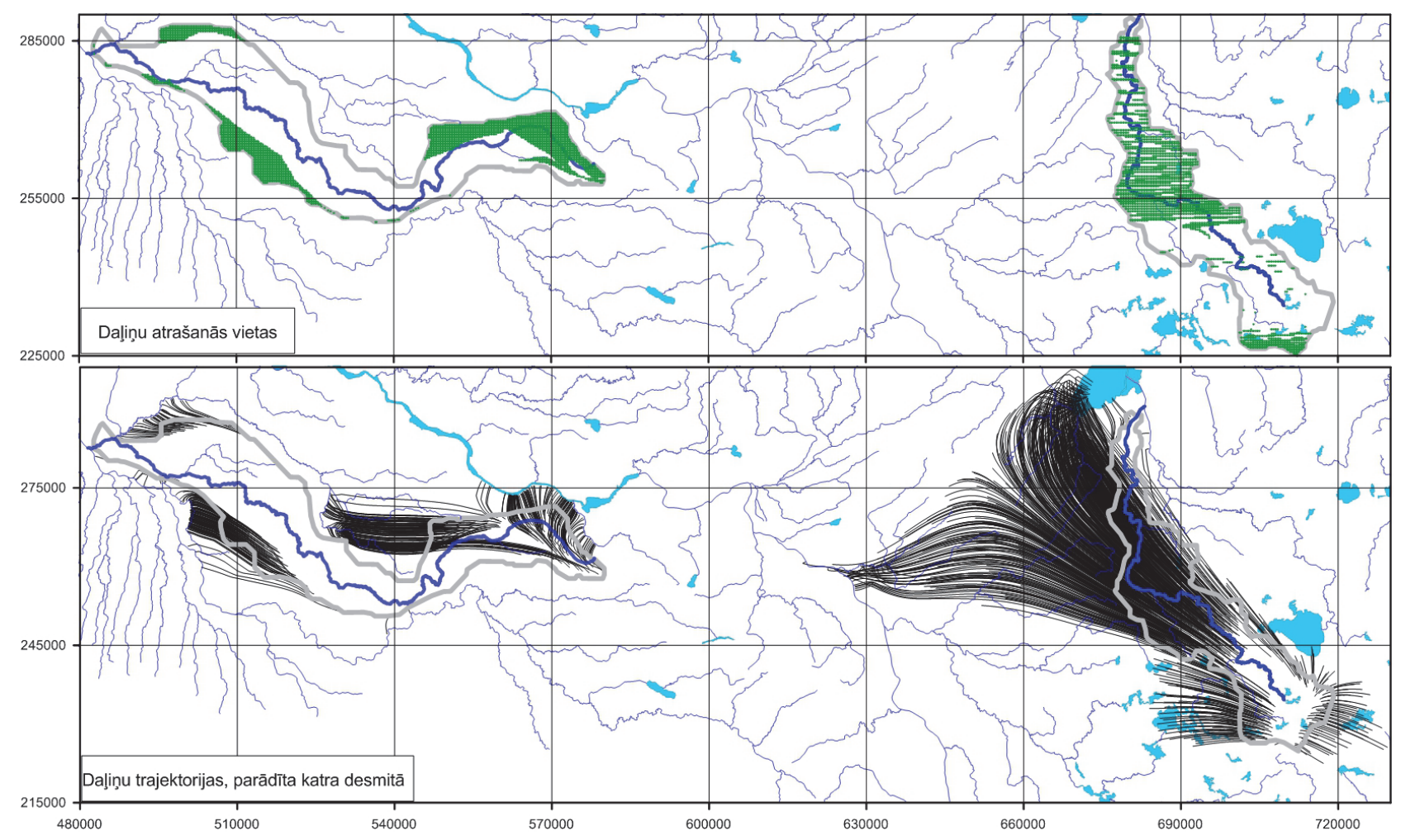

8. att. Daḷiņu novietojums un trajektorijas, kas iziet ārpus SB, startējot D3am slānī, forward režīms. 

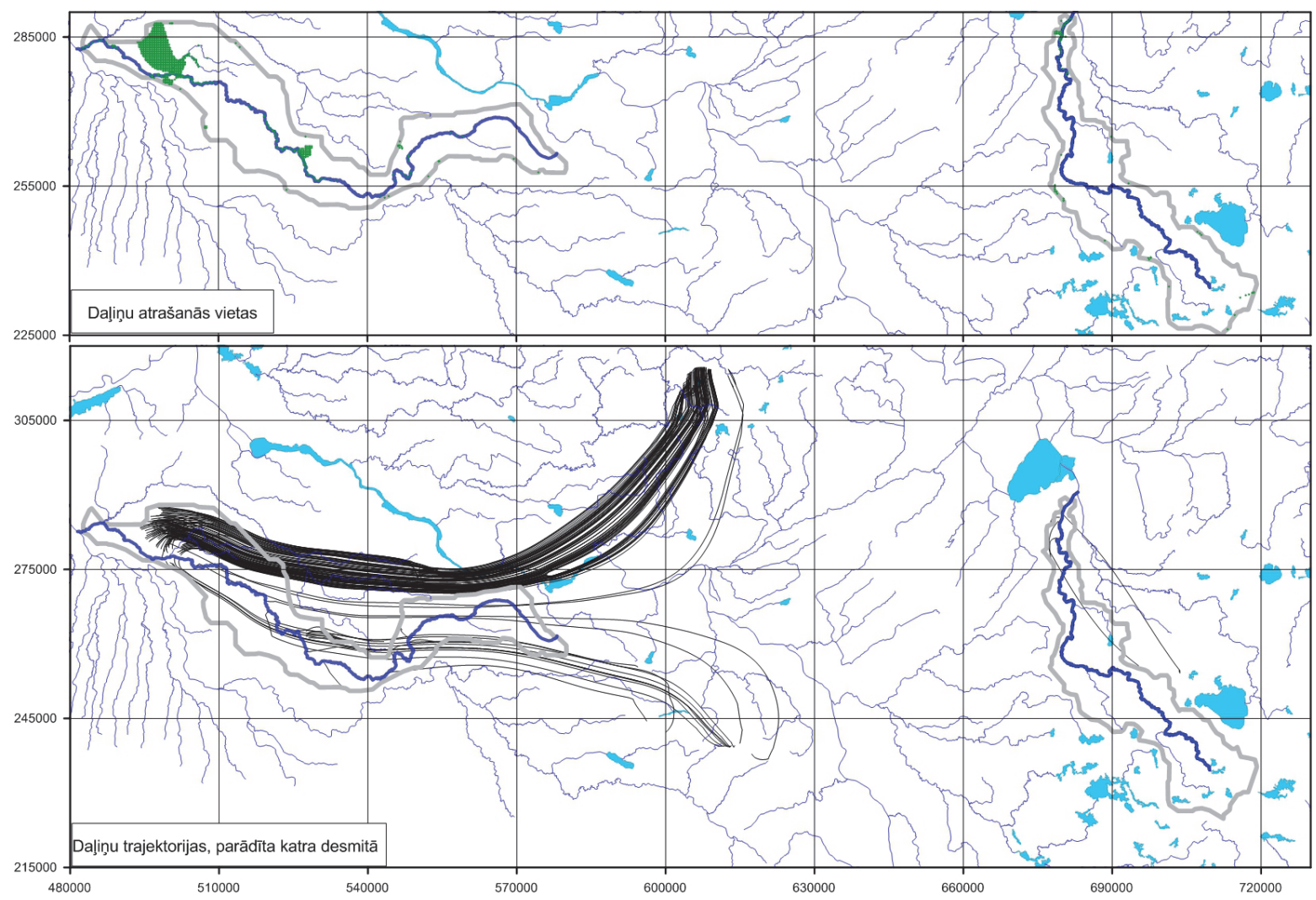

9. att. Dalịinu novietojums un trajektorijas, kas nāk no ārpuses SB, startējot Q2 slānī, reverse režīms.

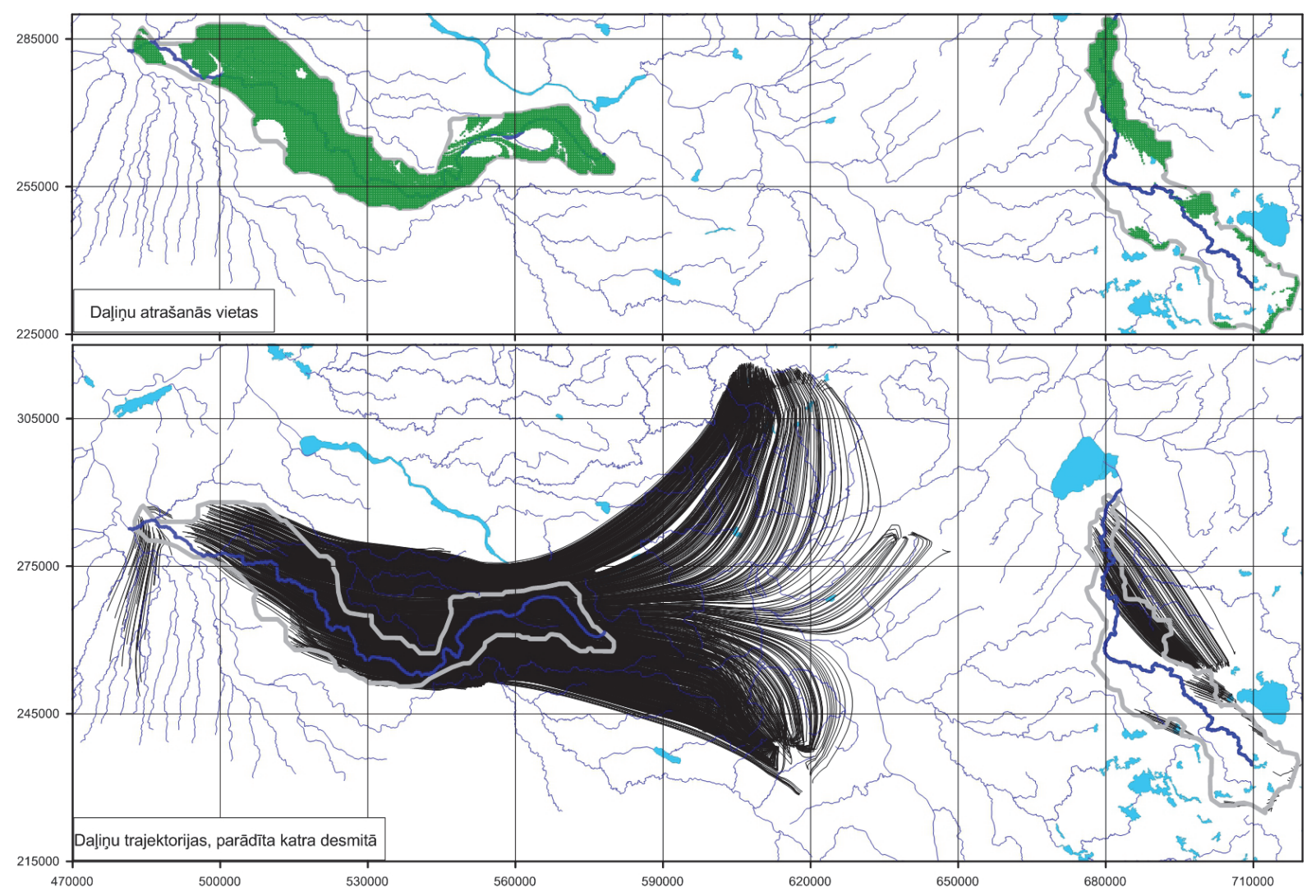

10. att. Daḷinuu novietojums un trajektorijas, kas nāk no ārpuses SB, startējot D3am slānī, reverse režīms. 


\section{SECINĀJUMI}

Latvijas hidroǵeoloǵiskā modeḷa LAMO vidē ir veikts skaitlisks eksperiments tipiskām zemienes (Iecava) un augstienes (Malta) upēm. Eksperimentu mērḳis bija pārbaudīt, vai šīm upēm piemērojams sateces apgabala kritērijs, t. i., vai visu pazemes ūdens plūsmu SB areāla tilpumā nodrošina atmosfēras nokrišni. Konstatēts, ka šo principu nosacīti var lietot tikai kvartāra Q2 slānim, bet nevienam pamatiežu slānim šo kritēriju lietot nevar. Šì iemesla dēḷ būs jākoriǵē pazemes ūdensobjektu robežas Latvijas ūdens resursu izmantošanas plānos. Pētîjumu finansēja Valsts Pētījumu programma EVIDEnT

\section{LITERATŪRAS SARAKSTS}

[1] Eiropas Padomes direktīva 98/83EK (1998. gada 3. novembris) par dzeramā ūdens kvalitāti. (in Latvian)

[2] K. Krauklis, A. Spalvins, and J. Slangens, "The Hydrogeological Model of Latvia LAMO4 as a Tool for Investigating the Processes of Nature. Sources of Groundwater Inflow for the Iecava River," Boundary Field Problems and Computer Simulation, vol. 54, pp. 43-50, 2015. https://doi.org/10.7250/bfpcs.2015.007

[3] A. Spalviñš and K. Krauklis, "Latvijas hidroǵeologiskais modelis LAMO4 kā rīks dabas procesu pētišanai. Iecavas upes pazemes pietecēs avoti," Latvijas Universitātes 74. zinātniskajā konferencēe, Zemes un vides zinātnu nozares sekcija, apakšsekcija "Lietiškā geoloǵija", Zinātnisko rakstu krājums. Rīgā, 5. Februārī 2016. (in Latvian)

[4] Latvijas hidroǵeologiskā modeḷa LAMO pilnveidošanas starprezultāti, Pārskats līgumam 2014/15 starp LVG̣MC un RTU, Riga, 2015. g. novembris, vad. A. Spalviņ̌s, teksts 30 lpp, pielikumi 53 lpp. (in Latvian) [Online]. Available:

http://www.emc.rtu.lv/VPP/ATSK_LVGMC 2015 teksts.pdf http://www.emc.rtu.lv/VPP/ATSK_LVGMC_2015_pielikumi.pdf

[5] D. W. Pollok, "User's Guide for MODDPATH/MODPATH-Plot, Version3. A particle tracking post-processing package for MODFLOW, the US Geological Survey finite-difference groundwater flow model," September 1994
[6] Golden Software, Inc., "SURFER-13 for Windows, Users manual, Guide to Using," 2015.

[7] Environmental Simulations, Inc., "Groundwater Vistas. Version 6, Guide to using," 2011.

[8] De Barry and A. Paul, Watersheds: processes assessment and management. Willey and Sons Inc. Hoboken, New Jersey, 2004, 700 p.

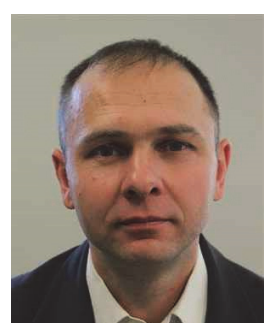

Kaspars Krauklis received the Master's Degree in Computer Systems from Riga Technical University in 2007 and the Certificate in Teaching of Engineering Sciences from the Institute of Humanities of RTU in 2005. Presently he is a Researcher with the Environment Modelling Centre and a Lecturer at the Department of Engineering Mathematics, RTU.

E-mail: Kaspars.Krauklis@gmail.com

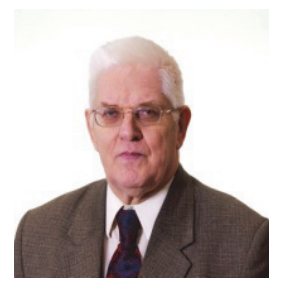

Aivars Spalvin̄š was born in Latvia. In 1963 he graduated from Riga Polytechnical Institute (Riga Technical University since 1990) as a Computer Engineer. $\mathrm{He}$ is Head of the Environment Modelling Centre of RTU. His research interests include computer modelling of groundwater flows and migration of contaminants.

E-mail: Aivars.Spalvins@rtu.lv

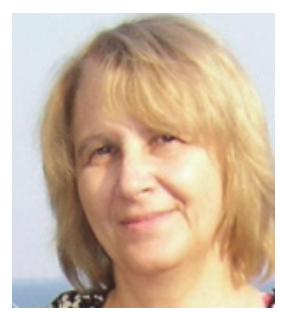

Irīna Eglīte received the Master's degree in Mathematics from the University of Latvia and the Master's degree in Applied Computer Science from Riga Technical University. She is a $\mathrm{PhD}$ student with RTU, a Researcher at the Environment Modelling Centre and a Lecturer with the Department of Engineering Mathematics, RTU. E-mail: Irina.Eglite@rtu.lv

Investigation of Latvian Rivers in Lowland and Hilly Areas by Using the Hydrogeological Model of Latvia

Kaspars Krauklis ${ }^{1}$, Aivars Spalviņš², Irina Eglīte ${ }^{3}$

${ }^{1-3}$ Riga Technical University, Latvia

The Water Framework Directive of European Union recommends applying the river drainage basin principle for defining the boundaries of groundwater bodies. This principle has been used in Latvia for establishing boundaries for the main water bodies of the country. By using the hydrogeological model of Latvia (LAMO), scientists of Riga Technical University tested the applicability of the principle for lowland (Iecava) and hilly (Malta) river drainage basins. The groundwater mass balances of basins were examined and the MODPATH particle tracking was applied. It was discovered that only for the Quaternary system, the principle can be used, because there the groundwater flow through the basin border was relatively small. The principle does not hold for the primary strata. In Latvia, drinking water is mostly provided by the primary strata. For this reason, the boundaries of the main groundwater bodies should be revised.

The research was supported by the Latvian State Research Program EVIDEnT.

Keywords - hydrogeological model, river drainage basin, balance of groundwater flows, MODPATH 